\title{
Hierarchy of human needs in the main character of beauty is a wound by Eka Kurniawan
}

\author{
Siska $^{\mathrm{a}, 1, *}$ \\ ${ }^{a}$ Litelature English Departement Ahmad Dahlan \\ ${ }^{1}$ siska@com.uad.ac.id*; \\ * corresponding author
}

Article history

Received 01-09-2020

Revised 12-11-2020

Accepted 13-11-2020

Keywords

Human hierarchy needs

psychology

Literature type studies

\begin{abstract}
On this research, the researcher has aim to find out the main character Dewi Ayu's human needs and identify the most dominant needs. In this study, the researcher applied the psychological approach and theory of human needs. This research is a qualitative descriptive study. The writer uses a library research method to collect the data. It means that the writer visit the library and reads the novel then read several related books. The main data is novel beauty is a wound by Eka Kurniawan, while supporting data is obtained from books, articles, and the internet. The result of this study can be explained that the main character can not totally fulfill well, such as: (1) the physiological needs of the main character can be fulfilled well because she is from a wealthy family (2) the safety can not be fulfilled due to factors in that era (3) the love and belonging need can be fulfilled well because the main character has a beautiful appearance (4) the esteem needs can be fulfilled because she is a famous figure at that time (5) self-actualization needs also can be fulfilled well because the main character is a brave and is able to position herself very well. From the five hierarchy needs the most dominant need is safety needs.
\end{abstract}

This is an open access article under the CC-BY-SA license.

\section{Introduction}

Literature is any writing, which has the power to move the readers' heart or stir their emottion ( Wiyono 1). It means that literature is an artistic of live of truth with modes in words and sound. Throught literature an author can write all of events in one country or place he or she lived. On the Collins dictionary literature is a written material such as poetry, novels, essays, drama, etc, especially works of imagination characterized by excellence of style and expression and by themes of general or enduring interst. Literature is composition that tells a story, dramatizes a situation, expresses emotions, analyzes and advocates ideas (Hijmans, 2020).

Writes that literature springs from our in born love of telling story, of arranging words inpleasing patterns, of expressing in words some special aspeects of our human experience (Kuo \& Chung, 2019). Defines of literature froma functional perspective as the imaginative work that gives us recreation, recognition, reveletion and redemption (Burton \& Burton, 2020) . After describing what he regarded as a literature,summed up that literature is a permanent expression in words of some thoughts or feelings in ideas about life and the world (Binnemans, Jones, Müller, \& Yurramendi, 2018).

From the three opinions, it was concluded that literature was in the form of expressions of thoughts and feelings, literature was also related to life experiences, words that were used were effective, strong and alluring. Lliterature also provides entertainment and inspires in the facts implied. Novel Beauty Is A Wound one of the best novel from indonesia which translated into some 
language ,told about history, satire, family tragedy, legend, humor, and romance in a sweeping polyphony. The beautiful Indo prostitute Dewi Ayu and her four daughters are beset by incest, murder, bestiality, rape, insanity, monstrosity, and the often vengeful undead. Kurniawan's gleefully grotesque hyperbole functions as a scathing critique of his young nation's troubled past:the rapacious offhand greed of colonialism; the chaotic struggle for independence; the 1965 mass murders of perhaps a million "Communists," followed by three decades of Suharto's despotic rule. (M.A.Orthofer)

Beauty Is A Wound is a novel full of passions, but rarely ones in which all parties are satisfied. Although she sells her body, Dewi Ayu determines who gets access, and under what conditions; even when she first is forced into prostitution she empowers herself as much as possible in how (and how little) she gives herself to her customers. Various relationships often come with strict conditions, including marriages that remain, at least for extended periods of time, sexless whether because the husband understands his bride is too young, or a wife physically prevents any chance at intercourse (one does resort to an actual chastity belt) while even those that are based on true love do not have happy endings (indeed, rarely even stand a chance). In strict body-count terms, Beauty Is A Wound is a brutal book: there are many deaths, some more shocking than others. (M.A.Orthofer)

There are many lessons in this novel can getten ,the researcher become more grateful to her life now , the researchers also found interst aspects such as ambition, don't falling in love too much , family, etc. Here the researcher wants to analyze the main character Dewi Ayu using psychology approach and viewed with Abraham Maslow's theory of Motivation.

\section{Theorotocal Framework}

Psychology is the scientific study of the mind and behavior. Psychology is a multifaceted discipline and includes many sub-fields of study such areas as human development, sports, health, clinical, social behavior and cognitive processes. Psychology is really a very new science, with most advances happening over the past 150 years or so. However, its origins can be traced back to ancient Greece, $400-500$ years BC. The emphasis was a philosophical one, with great thinkers such as Socrates influencing Plato, awho in turn influenced Aristotle.

Despite the failing of introspection Wundt is an important figure in the history of psychology as he opened the first laboratory dedicated to psychology in 1879, and its opening is usually thought of as the beginning of modern psychology. Wundt was important because he separated psychology from philosophy by analyzing the workings of the mind using more objective and standardized procedures.With its broad scope, psychology investigates an enormous range of phenomena: learning and memory, sensation and perception, motivation and emotion, thinking and language, personality and social behavior, intelligence, child development,mental illness, and much more. Furthermore, psychologists examine these topics from a variety of complementary psychological perspectives.

(Stoyanov, 2017) stated that people are motivated to achieve certain needs and that some needs take precedence over others : (1) Physiological needs - these are biological requirements for human survival, e.g. air, food, drink, shelter, clothing, warmth, sex, sleep. If these needs are not satisfied the human body cannot function optimally. Maslow considered physiological needs the most important as all the other needs become secondary until these needs are met. (2) Safety needs - protection from elements, security, order, law, stability, freedom from fear. (3) Love and belongingness needs - after physiological and safety needs have been fulfilled, the third level of human needs is social and involves feelings of belongingness. The need for interpersonal relationships motivates behavior Examples include friendship, intimacy, trust, and acceptance, receiving and giving affection and love. Affiliating, being part of a group (family, friends, work). (4) Esteem needs - which Maslow classified into two categories: (i) esteem for oneself (dignity, achievement, mastery, independence) and (ii) the desire for reputation or respect from others (e.g., status, prestige). Maslow indicated that the need for respect or reputation is most important for children and adolescents and precedes real self-esteem or dignity. (5) Self-actualization needs - realizing personal potential, self-fulfillment, 
seeking personal growth and peak experiences. A desire "to become everything one is capable of becoming"(Maslow 64).

The next is the researcher will use psychology approach and viewed with Abraham Maslow's theory of Motivation. Maslow's theory assumes that powerful people meet more basic (physiological) needs before directing behavior to meet higher needs (self manifestation). Lower needs must be fulfilled first before higher needs such as self-realization begin to restore one's behavior.

\section{Method}

The main data of this research is Beauty is a wound novel. In this reasearch the writer uses a library method to collect the data. It means that the writer visit the library and reading of the novel then write several related books. The writer also takes the data from the internet to get information of the novel completely, after reading, the researcher identyfying obtained data for the analysis and then classfying the data into same categories. The data analyzing technique used in research is descriptive qualitative. A technique whih is stated by statement, quotation and described by explanation. It is used to give more clear description about the study qualitatively by choosing , defining and arranging the fixed data (Ilyin \& Peirce, 2019).

\section{Results and Discussion}

This chapter contains of the analyzing of objectives of the study. The researcher explains about the hierarchy human needs of the main character analysis of Beauty Is a Wound. The researcher using Abraham Maslow's theory, the researcher also would identifies Dewi Ayu"s most dominant human needs. Maslow devides the Hierarchy of Human Needs into two part, those are deficiency needs and being need.

\section{A. Kind of Needs of Dewi Ayu in Beauty Is a Wound}

Actually there are many characters in this story such as; Mak gedik, Adinda, Alamanda, Maya dewi, si cantik and others, but again the most characters told is Dewi Ayu, so the researcher concludes that the Dewi Ayu is the main character. Dewi Ayu is a prostitute who described as a beautiful, stubborn and intelligent woman (de Clercq, 2013).

\section{Physiological Needs}

In the Beauty Is a Wound Dewi Ayu is a girl from wealthy family from the child her needs always can fulfilled because her family actually her grandpa was a dutchman, because in the colonial era only nobles who had wealth. It was different from the indigenous people who at that time were colonizes by the Dutch or Japanese so every her needs can be serve by maid even after she was adult and have daughters.

"Rosinah, the mute mountain girl who had been serving Dewi Ayu for years, led the woman into the bathroom, where she had prepared hot water in the tub." (Kurniawan, Raveinal, Fauzar, \& Arsyad, 2016).

So from here Dewi Ayu can can what she wants. The other physiological needs about food and water here Dewi Ayu also can fulfilled her hunger because she can still get food although she is in bad situation and mus struggle to get it. When she is being prostitute in Mama Kalong's house she still get a good service from the maids. The other physiological needs is clothes from the explanation she also can fulfill because she gets many beautiful gown and kabaya from Mama Kalong. She must always look beautiful in every situations. And because she is a postitute so her sex desire can fulfille well . So from the explanation we can conclude that Dewi Ayu can fulfilled her physiological needs very well.

\section{Safety Needs}

Dewi Ayu needs safety from violence, afraid, worry and freedom. Dewi Ayu feel worry to herself because she know that in Mama Kalong's house she will be a prostitute but here Dewi Ayu stay calm from her friends because she do not want ola and friends look worry too. Here Dewi Ayu 
can not escape from Mama Kalong she was being prostitute until she and other girls have an idea that they must sent letter to the leader of Japanese soldiers because a lot of the man who came to Mama Kalong's house are Japanese and her idea was succesful. But it just temporary because there are news that Japanese lose from England and there are still many indigenous who come to Mama Kalong's house. Here Dewi Ayu can not get freedom from Mama Kalong (Center for Food Safety and Applied Nutrition, 2012).

And the others safety needs is Dewi Ayu needs safety of violence Dewi Ayu already been a prostitute here but because it was first time to serve the man. She try to rebel but Dewi Ayu got coercion from the man, it cause Dewi Ayu get a little injured on her cheek. Dewi Ayu can not fulfilled her safety needs, because when she feel safety bacause Musasshi, the war was not over yet so she was still to be prostitute. She do not get freedom by Japanese soldiers, and she also do not get safety of violence by Mama Kalong or Japanese soldiers. She also feel guilty because the kindness of Mr willy that Dewi Ayu can not reply. He die when he save Dewi Ayu in Mama Kalong's house. So Dewi Ayu can not fulfill her safety needs well because she is still being prostitute until her half of life (Quinet, 2011).

\section{Love and Belonging Needs}

About love and belonging needs here Dewi Ayu get some love and careness from many people such as grandma, mak gedik, and Mr willy.

Her grandma very worries about Dewi Ayu because she do not want follow her to leave Halimunda, her grandma cry for her but Dewi Ayu still stubborn to stay until Mr Willy, her grandpa's bodyguard worries to her because she always muse and finally Mr. Willy asked to Dewi Ayu to merry him but Dewi Ayu deny because Dewi Ayu regard Mr willy as her brother.

"Those were trying times for Dewi Ayu because Mr. Willie still professed his deep love for her, and even though he had come up against her rejection before, he seemed ready to come up against it once again". (Kurniawan et al., 2016).

Beside Mr. Willy there is Maman Gendeng who love Dewi Ayu too. As long as Dewi Ayu in Mama Kalong's house and Maman Gendeng still life there was nobody can touch Dewi Ayu. He save Dewi Ayu from other mans but again Dewi Ayu deny him, otherwise Dewi Ayu asked Maman Gendeng to merry her daughter Maya Dewi.

So from the explanation above Dewi Ayu can met love and belonging needs very well.

\section{Esteem Needs}

The first esteem needs is esteem of others. Esteem of others is very important for the main character. There are some esteem needs of others that the researcher found . we can see from the narrated : "This is my house," she said in explanation. "What is your name?". "Beauty.". "I'm your mother," she added, (Kurniawati, Liana, Asharina, \& Permana, 2018).

The first time she thought was Rosinah so she was hurry up to go home because she missed Rosinah already, but from far she saw the gar who was sitting in the chair, she relized that the girl who sitting in the chair is her daughter was birthed eleven day before she died. From the quotes above, we can see that Dewi Ayu needs esteem of other. Here Dewi Ayu get respect and appreciation easily because she is beautiful and interesting.

And after the rose Dewi Ayu for a number of days, Dewi Ayu, busy with the visits of old friends who wanted to hear stories about the world of the dead, could ignore the presence of the annoying monster in her house. Even the kyai, who years ago had led her funeral with reluctance and looked at her with the disgust a young girl feels for earthworms, came to visit her with the virtuous manners of the pious in front of a saint, and with sincerity said that her rising again was like a miracle, and surely no one would be granted such a miracle if she wasn't pure. Here Dewi Ayu want to show that she is now a pure woman and the kyai believe and leave her haouse with enthusiastic.

From the explanation above we can see that Dewi Ayu can fulfilled her esteem need well.

\section{Self-Actualization Needs}


Self-actualization according to Maslow is "the identification of the phsysiological need for growth, development, and utilization of potential" (Kurland, 1975). Dewi Ayu was a intellegent woman, she always improve herself in all of condition althought she was on bad situation. She would try to find the way to solve the problem . it can be seen from :

"She wracked her brains trying to figure out what they were going to eat every day." (Eka Kurniawan, 2015:59)

"One day Dewi Ayu saw a baby crocodile at the edge of the delta, and knowing that the only thing you really need to avoid with a crocodile on shore is its tail, she bludgeoned its head with a large stone". (Eka Kurniawan, 2015:59)

From the narrated above Dewi Ayu try to cool down other friends who worry because they do not gave food from the soldiers. Dewi Ayu try to look for the food altought she must catch the baby crocodile with her way which learned by Mr. Willy and grandfather. Here Dewi Ayu want to show to other that she is a brave and smart girl, she wants to show that she has smart brain. Because her brain and brave her friend appoint Dewi Ayu as a leader it can be seen from :

"Despite her youth, Dewi Ayu was chosen as the head of her group. She was already mature enough to lead, and had nobody to distract her. In addition to her small school, she'd also found a doctor and they started a hospital without beds or medicine." (Eka Kurniawan, 2015:56)

So from the narrated above Dewi Ayu can find her self-fulillment as solution-oriented because she can solve the problem and she can achive what she wants.

The other self-actualization can seen from :

"Don't you feel like something strange is going on? Aren't you worried about anything?"

"Worry comes from ignorance," said Dewi Ayu.

"So you think you know what is going to happen to us?" asked Ola. "Yes," she replied, "we are going to be made into prostitutes." They all knew it, but only Dewi Ayu was brave enough to say it". (Eka Kurniawan, 2015:68)

Based on Abraham Maslow being realistic is one of the features from self-actualization. Here Dewi Ayu can read the situation easily, it means she always try to be a girl who think realistic. Dewi ayu always stay calm and no worry about anything although in bad situationin in front of her friends she want to show to her friends that she is feeling well, here she wants to get many respect from her friends and she wants to be center all of the problem, she wants her friends always depend on her and other reason she wants make ola and friends no worries because see her stay calm.

The other features self-actualization is creativity. Here Dewi Ayu copied her fashion throught the magazine even it makes other girl jealous to her because she had a good fashion. From the quote Dewi Ayu want to see different from others here Dewi Ayu want to look more than other. Even this unconsciously made the girls jealous because there are man like her and she could attract the attention of the top brass on that time (Beltrami, Kim, \& Rolkens, 2020).

So from the explanation Dewi Ayu can fulfill self-actualization from solution oriented, she can get food to eat because the soldiers do not give them many foods with her way, her desire want to a famous girl is succes she made . now she is being a popular girl in Halimunda because her brain and beauty. Here Dewi Ayu can fulfill her self-actualization very well.

\section{B. The Most Dominant Need of Dewi Ayu in Beauty Is a Wound}

The most dominant need in the main character is safety-needs because in the novel Dewi Ayu is a beautiful, stubborn, brave and smart girl, but she cannot fulfills her safety needs even to be freedom because she lived in colonization era and Japanese government who take over Halimunda so the Dutch people being the prisoner. Because Dewi Ayu was a dutchness so she is brought to a placed where she and others irrlander woman become prisoners. Mama Kalong's house is a prostitute place which was beautiful irrlander woman was gathered then bring to there. Here actually Dewi Ayu's heart ignored to be a whore but she also cannot run away because there are many soldiers who save this house, Although she look very calm but in her heart she do not want to be a 
whore. Here she cannot run also because Mama Kalong keeps their prostitute girl tightly. "After they had all left, Dewi Ayu walked to the window and opened it. There were thick iron bars and she said to herself, "There is no way to escape." (Eka Kurniawan, 2015:65). From the narrated Dewi Ayu try to look for the way to escape but it can not. From the freedom of guilty Dewi Ayu also can not fulfills well and freedom of afraid althought Dewi Ayu year by year she became the popular prostitute in Halimunda but it can not cover her fair about How if her children became prostitute like her , if her children asked where is her father and social sanction will she get in her around. So It can be conclude that Dewi Ayu cannot fulfill her safety need well because when she feel freedom to be prostitute it just temporary the reality she had been slept with many man and have four daughters from different man.

\section{Conclusion}

This chapter contains the conclusion of this research. From the analysis of the research, having analyzed Beauty Is a Wound Novel by Eka Kurniawan the researcher comes into the last chapter which deal with the conclusion, the following conclusion can be described dealing with the kinds of human needs according to Maslow's Hierarchy of Human Needs and the ways for fulfilling those needs as a creatures as seen in the main character in Dewi Ayu.

First, Dewi Ayu fulfills psychological needs by eating delicious foods, wearing good clothes like kebaya, desiring her sex, and sleep in the good badrooom. Second, safety needs : she can not fulfill her safety needs because she can not get her freedom in her era she still being a prostitute until she is not young again. Third, Dewi Ayu fulfills her love and belonging needs by Mr. Willy and Maman Gendeng but her grandma also show her love with her careness when Dewi Ayu do not want to follow her to leave Halimunda. Then, she fulfill her esteem needs are more from esteem to others. She gets appreciate,respect and others. The last she can fulfill her self-actualization well with her brain she try do the best as they can and she always act like she wants. And the most dominant needs from the main characters is safety needs because Dewi Ayu wants to get freedom but she can not.

\section{References}

Beltrami, M., Kim, D., \& Rolkens, F. (2020). The State of Fashion 2020. In McKinsey \&Company.

Binnemans, K., Jones, P. T., Müller, T., \& Yurramendi, L. (2018). Rare Earths and the Balance Problem: How to Deal with Changing Markets? Journal of Sustainable Metallurgy. https://doi.org/10.1007/s40831018-0162-8

Burton, S., \& Burton, S. (2020). Day 1. In The ELSA Trainers' Manual. https://doi.org/10.4324/9781003072447-7

Center for Food Safety and Applied Nutrition. (2012). Foodborne Illnesses: What You Need to Know.

de Clercq, R. (2013). Beauty. In The Routledge Companion to Aesthetics. https://doi.org/10.4324/9780203813034

Hijmans, R. J. (2020). raster: Geographic analysis and modeling with raster data. : R Package Version 3.1-5.

Ilyin, M., \& Peirce, C. (2019). WHAT IS A SIGN? In METOD. https://doi.org/10.31249/metod/2019.09.25

Kuo, P. H., \& Chung, Y. C. E. (2019). Moody microbiome: Challenges and chances. Journal of the Formosan Medical Association. https://doi.org/10.1016/j.jfma.2018.09.004

Kurland, A. A. (1975). Maslow. The Journal of Nervous and Mental Disease. https://doi.org/10.1097/00005053-197506000-00012

Kurniawan, E., Raveinal, R., Fauzar, F., \& Arsyad, Z. (2016). Nilai Diagnostik Metode "Real Time" PCR GeneXpert pada TB Paru BTA Negatif. Jurnal Kesehatan Andalas. https://doi.org/10.25077/jka.v5i3.609

Kurniawati, A., Liana, L., Asharina, N. P., \& Permana, I. (2018). Kajian Feminisme dalam Novel Cantik Itu Luka Karya Eka Kurniawan. Parole (Jurnal Pendidikan Bahasa Dan Sastra Indonesia). 
Quinet, K. (2011). Prostitutes as victims of serial homicide: Trends and case characteristics, 1970-2009. Homicide Studies. https://doi.org/10.1177/1088767910397276

Stoyanov, S. (2017). A theory of human motivation. In A Theory of Human Motivation. https://doi.org/10.4324/9781912282517 